\title{
Front Matter: Volume 10043
}

, "Front Matter: Volume 10043," Proc. SPIE 10043, Diagnosis and Treatment of Diseases in the Breast and Reproductive System, 1004301 (12 April 2017); doi: $10.1117 / 12.2268490$

SPIE. Event: SPIE BiOS, 2017, San Francisco, California, United States 


\title{
PROGRESS IN BIOMEDICAL OPTICS AND IMAGING
}

\section{Diagnosis and Treatment of Diseases in the Breast and Reproductive System}

\author{
Melissa C. Skala \\ Paul J. Campagnola \\ Editors
}

28-29 January 2017

San Francisco, California, United States

Sponsored by

SPIE

Cosponsored by

Thorlabs (United States)

Published by

SPIE 
The papers included in this volume were part of the technical conference cited on the cover and title page. Papers were selected and subject to review by the editors and conference program committee. Some conference presentations may not be available for publication. The papers published in these proceedings reflect the work and thoughts of the authors and are published herein as submitted. The publisher is not responsible for the validity of the information or for any outcomes resulting from reliance thereon.

Please use the following format to cite material from these proceedings:

Author(s), "Title of Paper," in Diagnosis and Treatment of Diseases in the Breast and Reproductive System, edited by Melissa C. Skala, Paul J. Campagnola, Proceedings of SPIE Vol. 10043 (SPIE, Bellingham, WA, 2017) Seven-digit Article CID Number.

ISSN: 1605-7422

ISSN: 2410-9045 (electronic)

ISBN: 9781510605275

ISBN: 9781510605282 (electronic)

Published by

SPIE

P.O. Box 10, Bellingham, Washington 98227-0010 USA

Telephone +1 3606763290 (Pacific Time) · Fax +1 3606471445

SPIE.org

Copyright (C) 2017, Society of Photo-Optical Instrumentation Engineers.

Copying of material in this book for internal or personal use, or for the internal or personal use of specific clients, beyond the fair use provisions granted by the U.S. Copyright Law is authorized by SPIE subject to payment of copying fees. The Transactional Reporting Service base fee for this volume is $\$ 18.00$ per article (or portion thereof), which should be paid directly to the Copyright Clearance Center (CCC), 222 Rosewood Drive, Danvers, MA 01923. Payment may also be made electronically through CCC Online at copyright.com. Other copying for republication, resale, advertising or promotion, or any form of systematic or multiple reproduction of any material in this book is prohibited except with permission in writing from the publisher. The CCC fee code is 1605 $7422 / 17 / \$ 18.00$.

Printed in the United States of America.

Publication of record for individual papers is online in the SPIE Digital Library.

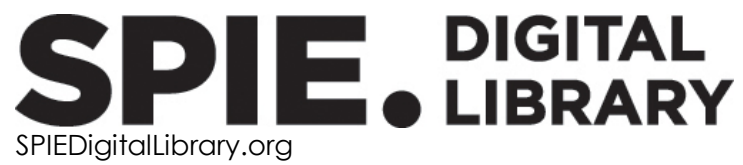

Paper Numbering: Proceedings of SPIE follow an e-First publication model, with papers published first online and then in print. Papers are published as they are submitted and meet publication criteria. A unique citation identifier (CID) number is assigned to each article at the time of the first publication. Utilization of CIDs allows articles to be fully citable as soon as they are published online, and connects the same identifier to all online, print, and electronic versions of the publication. SPIE uses a seven-digit CID article numbering system in which:

- The first five digits correspond to the SPIE volume number.

- The last two digits indicate publication order within the volume using a Base 36 numbering

system employing both numerals and letters. These two-number sets start with 00, 01, 02, 03, 04, $05,06,07,08,09,0 A, 0 B \ldots$. 0Z, followed by 10-1Z, 20-2Z, etc.

The CID Number appears on each page of the manuscript. The complete citation is used on the first page, and an abbreviated version on subsequent pages. 


\title{
Contents
}

\author{
$\checkmark \quad$ Authors \\ vii Conference Committee
}

\section{BREAST CANCER}

10043 OF Improving breast cancer diagnosis by reducing chest wall effect in diffuse optical tomography [10043-13]

\section{DEVELOPMENTAL BIOLOGY}

10043 OK Light-sheet microscopy for quantitative ovarian folliculometry [10043-17]

$10043 \mathrm{OL} \quad$ A dual-modality optical coherence tomography and selective plane illumination microscopy system for mouse embryonic imaging [10043-18]

\section{CARDIOVASCULAR DEVELOPMENTAL BIOLOGY}

$100430 Q \quad$ Live dynamic analysis of the developing cardiovascular system in mice [10043-23]

POSTER SESSION

10043 0X Density-based clustering analyses to identify heterogeneous cellular sub-populations [10043-30]

$100430 Z$ Rare-earth doped nanocomposites enable multiscale targeted short-wave infrared imaging of metastatic breast cancer [10043-39]

1004310 Optical coherence microscopy with extended focus for in vivo embryonic imaging [10043-31]

1004311 Brillouin microspectroscopy assessment of tissue differentiation during embryonic development [10043-32]

1004314 Structured light profilometry for designated breast surface coordinate variation analysis [10043-36]

1004315 3D mapping of breast surface using digital fringe projection [10043-37] 
Proc. of SPIE Vol. 10043 1004301-4

Downloaded From: https://www.spiedigitallibrary.org/conference-proceedings-of-spie on 26 Apr 2023 Terms of Use: https://www.spiedigitallibrary.org/terms-of-use 


\section{Authors}

Numbers in the index correspond to the last two digits of the seven-digit citation identifier (CID) article numbering system used in Proceedings of SPIE. The first five digits reflect the volume number. Base 36 numbering is employed for the last two digits and indicates the order of articles within the volume. Numbers start with 00, 01, 02, 03, 04, 05, 06, 07, 08, 09, OA, OB...0Z, followed by 10-12, 20-2Z, etc.

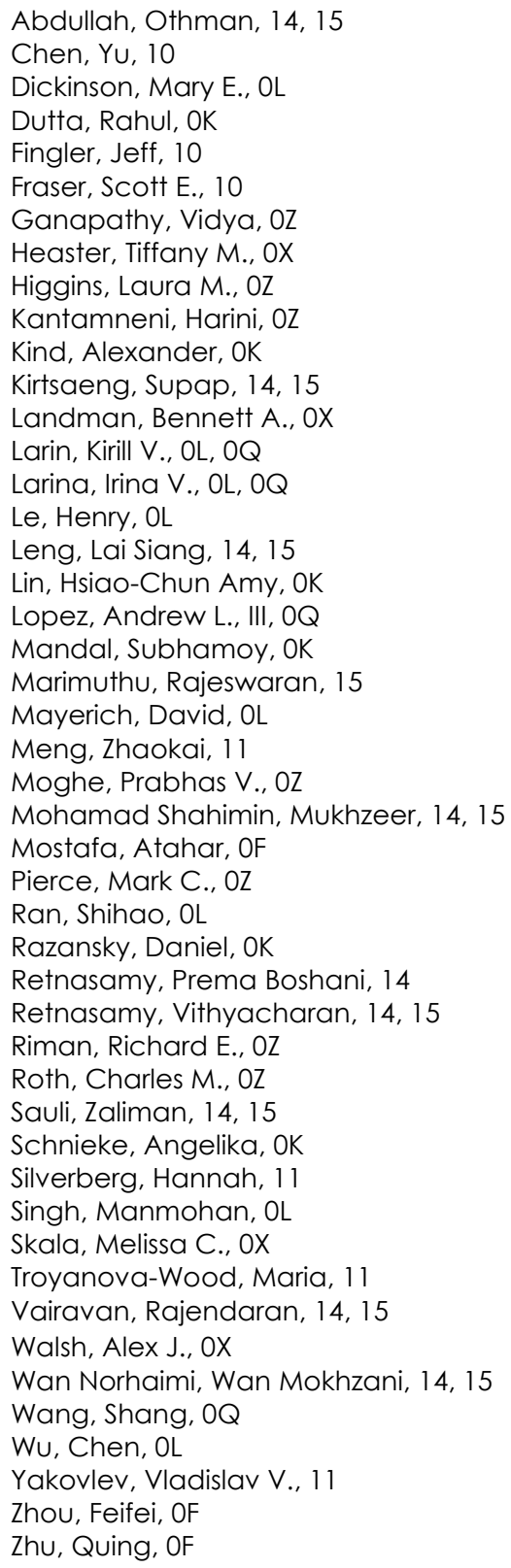


Proc. of SPIE Vol. 10043 1004301-6

Downloaded From: https://www.spiedigitallibrary.org/conference-proceedings-of-spie on 26 Apr 2023 Terms of Use: https://www.spiedigitallibrary.org/terms-of-use 


\title{
Conference Committee
}

\author{
Symposium Chairs
}

James G. Fujimoto, Massachusetts Institute of Technology

(United States)

R. Rox Anderson, Wellman Center for Photomedicine, Massachusetts General Hospital (United States) and Harvard School of Medicine (United States)

Program Track Chair:

Brian Jet-Fei Wong, Beckman Laser Institute and Medical Clinic (United States)

\section{Conference Chairs}

Melissa C. Skala, Morgridge Institute for Research at the University of Wisconsin, Madison (United States)

Paul J. Campagnola, University of Wisconsin-Madison (United States)

Conference Program Committee

Ji-Xin Cheng, Purdue University (United States)

Darren M. Roblyer, Boston University (United States)

Anita Mahadevan-Jansen, Vanderbilt University (United States)

Bruce J. Tromberg, Beckman Laser Institute and Medical Clinic (United States)

\section{Session Chairs}

1 Gynocology

Melissa C. Skala, Morgridge Institute for Research at the University of Wisconsin, Madison (United States)

2 Drug Response and Prognosis

Paul J. Campagnola, University of Wisconsin-Madison (United States)

3 Tumor Margin Assessment

Darren M. Roblyer, Boston University (United States)

4 Breast Cancer

Anita Mahadevan-Jansen, Vanderbilt University (United States) 
5 Developmental Biology

Andrew M. Rollins, Case Western Reserve University (United States)

6 Cardiovascular Developmental Biology

Michael Andrew Choma, Yale School of Medicine

(United States) 